\title{
A Kind of Neither Keynesian Nor Neoclassical Model (7): The Cause of the Financial Crisis
}

\author{
Zhan Zhan', Ming'an Zhan² \\ ${ }^{1} \mathrm{KU}$ Leuven, Leuven, Belgium \\ ${ }^{2}$ Yunnan University, Kunming, China \\ Email: blacktea1313ryan@hotmail.com, 1792481782@qq.com
}

How to cite this paper: Zhan, Z. and Zhan, M.A. (2018) A Kind of Neither Keynesian Nor Neoclassical Model (7): The Cause of the Financial Crisis. Open Access Library Journal, 5: e5084.

https://doi.org/10.4236/oalib.1105084

Received: November 30, 2018

Accepted: December 22, 2018

Published: December 25, 2018

Copyright $\odot 2018$ by authors and Open Access Library Inc.

This work is licensed under the Creative Commons Attribution International License (CC BY 4.0).

http://creativecommons.org/licenses/by/4.0/

\section{cc) (i) Open Access}

\begin{abstract}
There are two reasons for the financial crisis. One is the spontaneous speculation in the capital market. The P/E ratio of the speculative object is much higher than the ratio of capital to output in the factual economic system. The other is the crisis triggered by the bubble environment. In addition, inflation has a strong inhibitory effect on asset bubbles, and high inflation and asset bubbles will not occur at the same time. These can be verified by statistical data and theoretical explanation from the marginal state equation of Cobb-Douglas function.
\end{abstract}

\section{Subject Areas}

Economic System

\section{Keywords}

Cobb-Douglas Function, P/E Ratio, Endogenous Earnings, Exogenous Earnings

\section{Introduction}

Warren Buffett said that it is foolish to buy a stock whose price is 20 times its earnings when the interest rate is $15 \%$. Because the price per share/earning per share $(\mathrm{P} / \mathrm{E}$ ratio or $\mathrm{P} / \mathrm{E})$ is $1 / 0.5=6.7$ for the interest rate $r=15 \%$. This is actually the principle of opportunity cost that is determined by the stock value. Why this theoretically reliable and easily operable method cannot make everyone become Buffett?

If the S\&P $500 \mathrm{P} / \mathrm{E}$ ratio is compared with the $1 / r$ of the same period, in the 90 years of 1890-1980 (including the famous Great Depression of 1929), the stock $\mathrm{P} / \mathrm{E}$ ratio is almost always in a profitable state in which it is less than the interest 
rate $\mathrm{P} / \mathrm{E}$ ratio. In most years during 1980-2017, the stock $\mathrm{P} / \mathrm{E}$ is greater than the interest $\mathrm{P} / \mathrm{E}$. It seems that Buffett's secret is not limited to the principle of opportunity cost. Below we try to define three P/Es from the perspectives of the capital market, the factual economy and the virtual economy, and then analyze the value of the asset and the reasons for the fluctuation of the capital market in their comparison.

\section{The Characteristics of Asset $K$ in the Cobb-Douglas Function}

Cyclical changes are an important characteristic of macroeconomic variables, and capital markets are no exception. In the previous paper, we have divided eight complete business cycles according to the change of interest rate $r$ in the United States from 1970 to 2016 [1]. Looking at it now, interest rate $r$ has changed from a decline in 2016 to an increase in 2017, so it can be initially confirmed that 2012-2016 is the ninth cycle since 1970-2016, as shown in Figure 1.

In recent years, the fluctuation of market interest rate $r$ has become smaller and smaller under the control of the Federal Reserve. The business cycle characteristics of macro variables have become weaker and weaker, and the boundaries of the business cycle are somewhat blurred. In theory, the cyclical characteristics of inflation rate $\dot{P}$ are generally consistent with interest rate $r$ fluctuations, while the change rate of inflation rate $\ddot{P}$ is far greater than the interest rate $r$ and the inflation rate $\dot{P}$ [2]. This can also be used to divide the period or to verify the period of other methods.

As shown Figure 1 in and Figure 2, the inflation rate $\dot{P}$ in 1983-2017 is not as volatile as the interest rate $r$, but the change rate of the inflation rate $\ddot{P}$ has a relatively large increase and decrease in each cycle. Since $\ddot{P}$ increased largely in 2014 and declined largely in 2015, 2012-2016 should be divided into a cycle. Judging from the low point of $\ddot{P}$, both 2015 and 2016 can be used as the demarcation point of the previous cycle. This is because the periodic boundary divided by annual statistics cannot be accurate to the time point of a certain month, so only one can be selected as the starting point of the next cycle. Since the interest rate $r$ shows a demarcation in 2016, we have determined the cycle demarcation point as 2016 .

In the traditional macroeconomic theory, the Cobb-Douglas function is generally only used to explain two aspects: one is the relationship between production factors and output, and the other is use the total differential equation $Y / Y=d Y / Y=d A / A+\alpha d K / K+\beta d L / L$ to calculate the so-called total factor productivity $d A / A$. The application on the first aspect is limited to the abstract interpretation of the source of national income. As for the second aspect, according to our theory, $A$ is an endogenous variable closely related to interest rate $r$, and $d A / A$ is a reflection of the fluctuation of production efficiency [3]. Therefore, the total factor productivity cannot correctly explain the relationship between variables. 


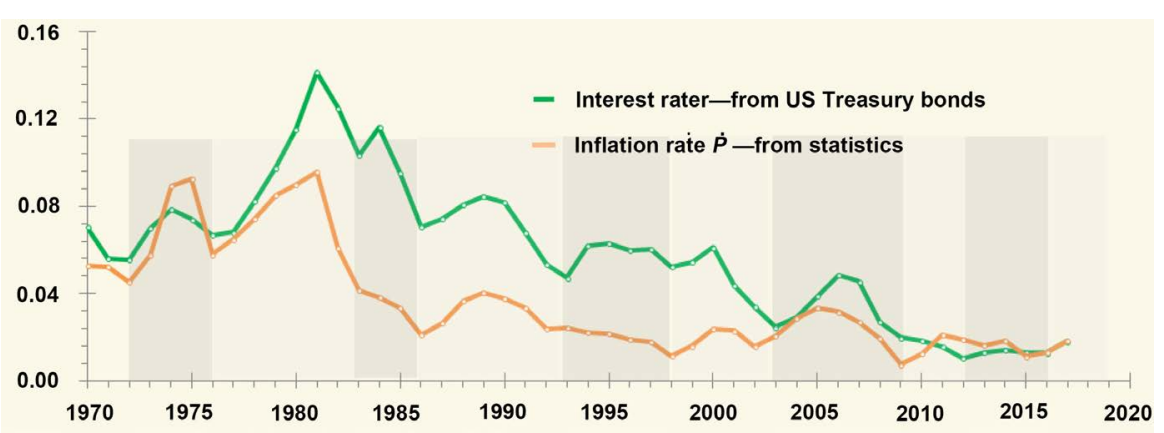

Figure 1. Business cycles (zebra crossing in the figure) divided by the change of interest rate $r$. Resources: 1) Interest rate $r$ is the arithmetic mean of annualized earnings of various US Treasury bonds, data are from http://www.federalreserve.gov/. See paper "A Kind of neither Keynesian nor Neoclassical Model (2): the Business Cycle" [1]. 2) The inflation rate $\dot{P}=d P / P \approx \Delta P / P$. The price index $P$ is calculated from the nominal GDP and real GDP by the deflator. Data of nominal and real GDP are from http://www.bea.gov. See the paper "A Kind of neither Keynesian nor Neoclassical Model (2): The Inflation Equation" $[2]$.

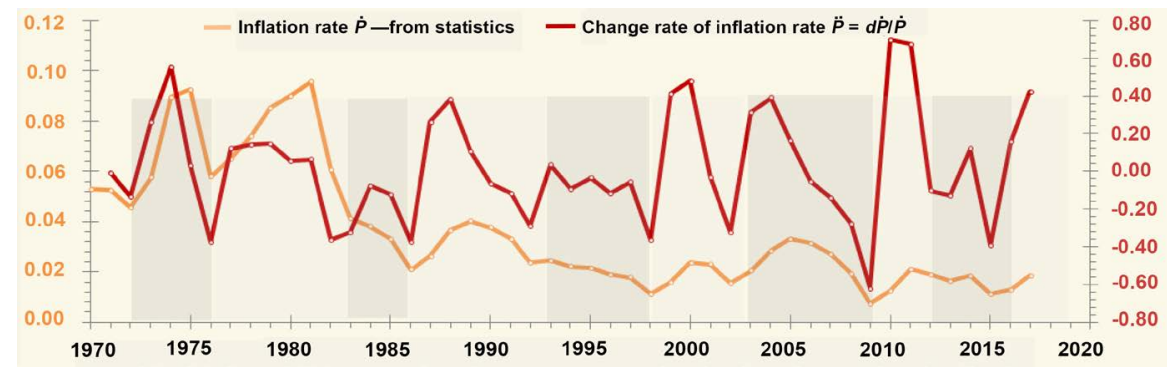

Figure 2. Business cycle divided by the rate of change $\ddot{P}$ of the inflation rate $\dot{P}$. Resources: Inflation rate $\dot{P}$ is the same as Figure 1 . The change rate of inflation rate $\ddot{P}=d \dot{P} / \dot{P} \approx \Delta \dot{P} / \dot{P}$. See the paper "A Kind of neither Keynesian nor Neoclassical Model (2): The Inflation Equation" [2].

In fact, as long as the marginal state equation $K=\alpha Y / r$ of the Cobb-Douglas function is used, it does not matter how we recognize $A$, because the role of $A$ is implicit in the marginal state equation $K=\alpha Y / r$. Not only that, $V$ is used to analyze macroeconomic problems, and it is also possible to eliminate the misunderstanding and application of the factor $L$ when people use the Cobb-Douglas function $Y=A K^{\alpha} L^{\beta}$.

Assuming that the marginal variable $\partial K / \partial Y$ in Cobb-Douglas function $Y=A K^{\alpha} L^{\beta}$ equals interest rate $r$, the marginal state equation $K=\alpha Y / r$ can be derived. It is the theoretical basis for analyzing the changes in investment, business cycle, Phillips curve, economic growth, etc. in previous papers [2] [3] [4] [5] [6], and it is also a basic model for analyzing how capital markets change in asset $K$ relative to output $Y$.

There are two different ways to measure the macro-asset $K$ : one is the private fixed assets directly from the statistical data, denoted as $K_{f}$; the other is calculated from the statistical data of output $Y(\mathrm{GDP})$, interest rate $r$ and the coefficient of output distribution $\alpha$ by equation $K=\alpha Y / r$, denoted as $K$. 
As shown in Figure 3, there is a big gap between $K$ and $K_{f}$ : First, the maximum value of $K$ calculated by the Cobb-Douglas function is about 16 times larger than the private fixed assets $K_{f}$ Secondly, $K_{f}$ has small fluctuations and stable growth, while $K$ has large fluctuations and has a tendency to accelerate growth.

There are two reasons for this: First, in addition to private fixed assets, $K$ has many assets that are not counted or difficult to count, such as a large number of house property; second, the calculation of asset $K$ is closely related to changes in market interest rate $r$, while the statistical asset $K_{f}$ is relatively little affected by the change of interest rate $r$.

$K$ calculated by the marginal state equation cannot be directly counted like $K_{f}$, so we call $K$ a virtual asset. In the marginal state equation $K=\alpha Y / r, Y$ is the benefit generated in the use of the production factor $K$ (in the Cobb-Douglas function $Y=A K^{\alpha} L^{\beta}$, the factor $L$ also contributes to the output $Y$, but the value of $L$ is also determined by $K[1])$. We call the ratio $K / Y$ of factor $K$ to output (earning) as the virtual $\mathrm{P} / \mathrm{E}$ ratio. Correspondingly, the ratio $K_{f} / Y$ from statistical date is the factual $\mathrm{P} / \mathrm{E}$ ratio. Later we will see that the so-called virtual economy is closely related to the change of $K$ or $K / Y$, and the factual economy is closely related to the change of $K_{f}$ or $K_{f} / Y$.

Stocks or house property are specific assets and speculative objects in the capital markets, or we can say they are carrier of capital markets. Their value and corresponding earnings are part of macro assets and macro returns (outputs), so we record them as $K_{i}$ and $Y_{i}$, and the corresponding ratio $K_{i} / Y_{i}$ is called the carrier P/E ratio. For example, in November 2017, the carrier P/E ratio of S\&P 500 Index was 26.

The virtual asset $K$ is not always much larger than the factual asset $K_{f}$. For example, $K$ and $K_{f}$ are relatively close during the period 1970-1985, and their average values are 8038 and 5265 billion dollars, respectively. If we further compare their rate of change, i.e. $d K / K$ and $d K_{f} / K_{f}$ (abbreviated as $\dot{K}$ and $\dot{K}_{f}$ ), $\dot{K}$ has a larger amplitude than $\dot{K}_{f}$, as shown in Figure 4 , in the financial crisis of 2008 , the maximum value $\dot{K}$ is 0.7657 , which is 31.64 times that of $\dot{K}_{f}$.

\section{Factors of Influencing Carrier P/E Ratio}

\subsection{Crisis Classification}

People are used to divide the economic crisis into financial crises and other types of crises, and then subdivide the financial crisis. The International Monetary Fund (IMF) divides the financial crisis into four categories in the World Economic Outlook 1998 [7]: 1) Currency Crises of the continuous depreciation of domestic currency and international currency exchange rate; 2) Banking Crises of large-scale debt default in domestic commercial banks; 3) Foreign Debt Crises of domestic sovereign debt and private debt has been widely defaulted abroad; 4) Systematic Financial Crises of these crises occurring simultaneously or 


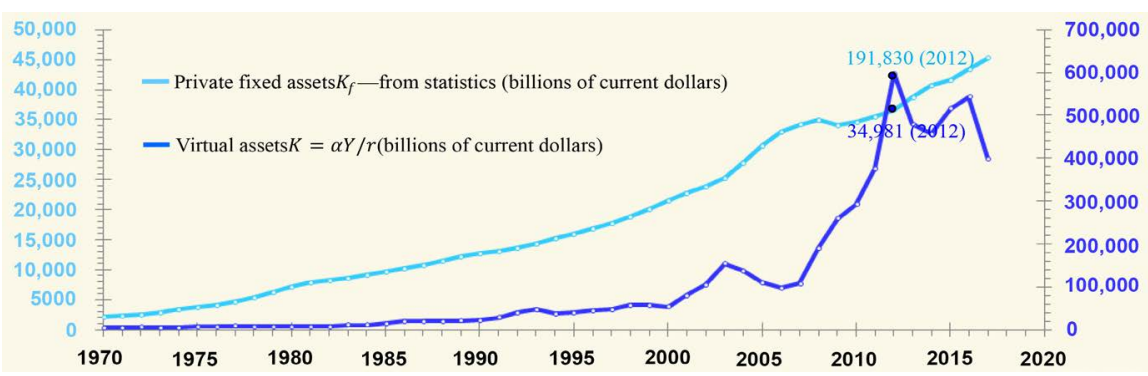

Figure 3. Private fixed assets $K_{f}$ and virtual assets $K$. Resources: 1) Data of Private fixed assets $K_{f}$ are from http://www.bea.gov. 2) Virtual assets $K=\alpha Y / r, \quad Y=$ GDP, $\alpha=1-\beta, \beta$ is the ratio of compensation of employees to GDP. Data of compensation of employees and GDP are from http://www.bea.gov. 3) Data of $r$ see Figure 1.

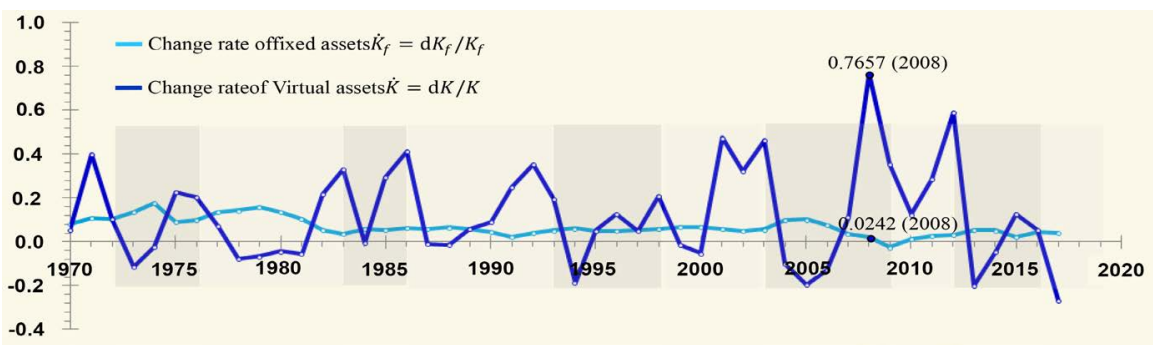

Figure 4. Change rate of fixed assets $\dot{K}_{f}$ and Change rate of Virtual assets $\dot{K}$. Resources: $\dot{K}_{f}=d K_{f} / K_{f} \approx \Delta K_{f} / K_{f}, \dot{K}=d K / K \approx \Delta K / K, \quad K_{f}$ and $K$ data are the same as in Figure 3. The business cycle of the zebra crossing in the figure is the same as in Figure 1.

successively. This classification may have its practicality, but this paper attempts to classify it from the perspective of highlighting the causes of the crisis, as shown in Figure 5.

In Figure 5, whether it is product or asset speculation, it is capital speculation for speculators. Only in the capital market speculation, asset speculation is more complicated and more comprehensive than product. For example, in stocks and house property markets, speculators are most concerned with the impact of the return on the value of the asset, that is, the value of the asset $K$ is bet based on the output $Y$. In the commodities market of oil, gold, grain, etc., people directly bet on the price fluctuation of $Y$. For the convenience of analysis, the following distinguishes the differences and connections between several commonly used concepts.

\subsection{The Difference and Connection between Capital and Assets}

Capital is either used to purchase output $Y$ or to purchase asset $K$ that produces output $Y$, which is money owned by market speculators. Money has good liquidity or selectivity. As shown in Figure 5, it can be used for both currency and product speculation, as well as for buying and selling various assets in the asset market.

Asset $K$ originally refers to the production factors of material form, such as land, labor tools, etc. If one of the assets is to be converted into another, it needs 


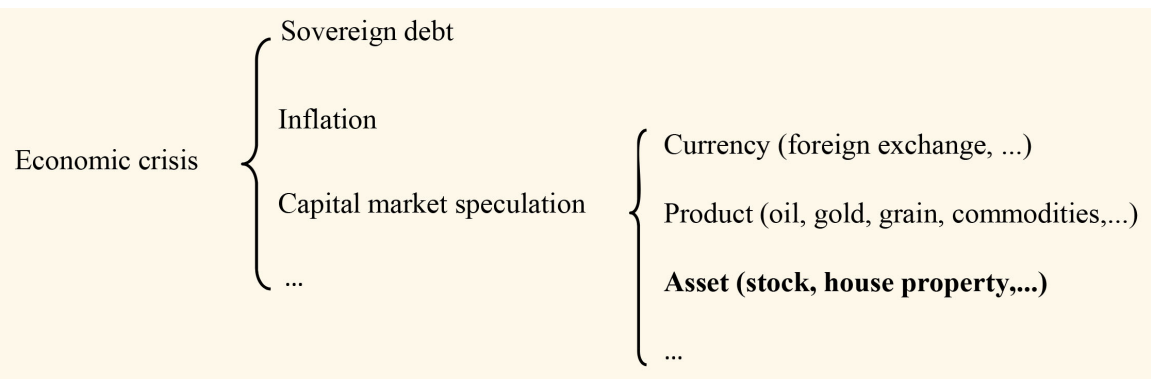

Figure 5. Economic crisis classification.

to be traded in the market. At this time, although the land is still the land, its value may not be as much as half of the previous one. So theoretically the liquidity of asset $K$ is not as good as money. If the asset $K$ of the material form can be converted into the monetary capital at any time without loss, the asset can also be called capital. The Cobb-Douglas function $Y=A K^{\alpha} L^{\beta}$ is sometimes referred to as capital, because $K$ is implicitly assumed to be a monetary asset that can be realized at any time. To be precise, the stock market and the house property market belong to the asset market and are a sub-category of the capital market.

Some trading objects in the market have both $Y$ and $K$ attributes, such as house property. Houses built with materials such as land, steel, cement, timber, etc. will certainly be included in the GDP of the year (i.e., output $Y$ ). Just as grain produced from land can fill people's stomachs, built houses can provide consumers with residential benefits, but food consumption is disposable, and houses can be used repeatedly.

Unlike food, the house that produced $Y$ in the previous period can be the asset $K$ of the next period, just as a certain tool was part of GDP in the year it was produced, and then became part of the fixed asset $K_{f}$. The $Y$ generated by the house that becomes the asset $K$ is the rent (even if it is not rented, the rent should be used as the opportunity cost of the house). Although house rents are also part of GDP, they are negligible compared to the GDP at the time of construction. Adam Smith did not pay much attention to the residential utility (expressed as rent) of the completed house. He said: "Though a house, therefore, may yield a revenue to its proprietor, and thereby serve in the function of a capital to him, it cannot yield any to the public, nor serve in the function of a capital to it, and the revenue of the whole body of the people can never be in the smallest degree increased by it" [8]. In fact, it is the existence of residential utility that makes the house has the property of capital and can become a speculative object in the capital market.

\subsection{Endogenous and Exogenous Nature of Capital Earnings in Capital Market}

The endogenous earning means that some participants' earning $Y_{i}$ comes from others' capital $K_{i}$, while the exogenous earning means that the productive activities outside the game provide the participants' earning $Y_{i}$. 
All market speculation has clear targets or carriers, such as tulip bulbs, stocks, house properties, etc., just like the Ponzi scheme and the pyramid scheme have an appealing project. Although people's speculation in the stock or house property market is legal, its operation and collapse are very similar to the illegal Ponzi scheme or pyramid scheme, but people's earnings from the legitimate capital market is not entirely endogenous, or both exogenous and endogenous. The earnings (if any) of speculators in financial fraud is entirely endogenous. Because neither the Ponzi game, which is based on fabricating false stories, nor the pyramid game, which is based on developing offline, has factual earnings from outside. The sum of the earnings of all participants in the scam is 0 , and the $\mathrm{P} / \mathrm{E}$ of the scam is $K_{i} / Y_{i}=K_{i} / 0=\infty$.

Once endogenous earnings become the driving force behind a certain asset price rise, the collapse of the game or the bursting of the bubble is its fate. The more prosperous the Ponzi game, the more game money it needs. If there is not enough money to enter, people will trend away from the impact of an unexpected event, just like the trend when the game is booming.

According to John Law's theory [9], the never-ending Ponzi game must have two external conditions: 1) infinite money supply (encourage more money holders to play games). 2) Reducing speculators' expected rate of return until 0 (underpayment or zero payment of participants' returns can extend the cycle time in the market indefinitely). However, this is impossible for any game, so the more confident speculators are, the more serious the consequences will be.

With the rise of stock or house property index, people's exogenous earnings will be covered by endogenous earnings. Incremental capital $\Delta K_{i}$, which continuously enters the market, becomes the driving force of the rise of index. It is not that people are irrational, but that many listed companies do have potential for development in the boom period, even though some of their stories are false. Once the stock or house property index tends to rise, people are most worried about whether they will miss out on the immediate opportunity to make money, regardless of whether their earnings come from other people's capital, like the Ponzi game, or from the profits of companies.

\subsection{The Link between $\mathrm{P} / \mathrm{E}$ Ratio $K_{i} / Y_{i}, K_{f} / Y$ and $K / Y$}

From the moment a specific asset $K_{i}$ enters the capital market, its value is no longer the capital consumed by the trader when he purchases it, but is revalued according to its possible earnings (output) $Y_{i}$ and opportunity cost. One of the important indicators is the "asset value per unit income" $K_{i} / Y_{i}$, which is the carrier price-earnings ratio of microscopic nature. If the carrier $\mathrm{P} / \mathrm{E}$ ratio increases, $K_{i}$ will also increase as $Y_{i}$ remains unchanged. As mentioned above, there are still two kinds of $\mathrm{P} / \mathrm{E}$ in macroeconomic system: one is the factual $\mathrm{P} / \mathrm{E}$ $K_{f} / Y$, the other is the virtual $\mathrm{P} / \mathrm{E} K / Y$ determined by the marginal equation of state $K=\alpha Y / r$ of Cobb-Douglas function.

We don't know how the virtual $\mathrm{P} / \mathrm{E}$ ratio $K / Y$ and the factual $\mathrm{P} / \mathrm{E}$ ratio 
$K_{f} / Y$ will affect the operation of the economic system, but we can see from the marginal equation of state $K / Y=\alpha / r$ that the smaller the market interest rate $r$, the larger the $K / Y$. Since output growth rate $\dot{Y}$ in factual economy is also related to interest rate $r$ (e.g. $\dot{Y}=r+\dot{r}-\dot{\alpha}$ [2]), and output growth rate $\dot{Y}$ is the focus of capital market game, market interest rate $r$ is the bridge between factual $\mathrm{P} / \mathrm{E}$ ratio $K_{f} / Y$ and virtual $\mathrm{P} / \mathrm{E}$ ratio $K / Y$.

Because the earnings $Y_{i}$ in carrier $\mathrm{P} / \mathrm{E}$ ratio $K_{i} / Y_{i}$ is a part of macro output $Y$, there is a certain relationship between the factual $\mathrm{P} / \mathrm{E}$ ratio $K_{f} / Y$ and carrier $\mathrm{P} / \mathrm{E}$ ratio $K_{i} / Y_{i}$, and between the factual $\mathrm{P} / \mathrm{E}$ ratio $K_{f} / Y$ and the virtual $\mathrm{P} / \mathrm{E}$ ratio $K / Y$.

For example, when the output growth rate $\dot{Y}$ in the factual economy is much larger than the rate of return on some asset $\left(Y_{i} / K_{i}\right)$ in the hands of speculators, speculators buy long will be more profitable, and vice versa. On the other hand, if the government's monetary policy keeps the market interest rate $r$ down (thus pushing up the virtual $\mathrm{P} / \mathrm{E}$ ratio $K / Y$ ), the application of carrier asset $K_{i}$ will face a smaller opportunity cost, which will enhance people's confidence in doing so, even if the output growth rate $\dot{Y}$ in the factual economy does not increase at this time.

Although the virtual $\mathrm{P} / \mathrm{E}$ ratio $K / Y$ as opportunity cost often influences the change of carrier $\mathrm{P} / \mathrm{E}$ ratio $K_{i} / Y_{i}$, the factual $\mathrm{P} / \mathrm{E}$ ratio $K_{f} / Y$ is the long-term value center of carrier $\mathrm{P} / \mathrm{E}$ ratio $K_{i} / Y_{i}$. The actual source of capital market returns is exogenous income related to $K_{f} / Y$.

\section{Internal Causes and External Causes of Market Crises}

\subsection{Internal Causes}

Investment and speculation are attempts to use wealth (capital) to increase earnings. It is difficult to use greed or not to distinguish whether people's participation in market transactions is investment or speculation, because the meaning of greed itself is ambiguous. After clarifying the difference and connection between asset $K$ and output $Y$ in wealth, we can distinguish the difference between investment and speculation: the act of investing is to replace the capital (money) with a certain $K_{i}$ on the market and obtain the $Y_{i}$ generated by $K_{i}$. The characteristic is that the risk of loss of principal is small (such as deposits in banks to obtain interest, purchase of house property to obtain rent, long-term holding of blue-chip stocks to obtain dividends, etc.); and speculation is to replace capital with a certain $Y_{i}$ or $K_{i}$ on the market to obtain the difference in value fluctuations. The characteristic is that the risk of loss of principal is very high. (Such as buying and selling foreign currency, commodity futures, stocks and house property etc.).

Few people would say not to the dividend income $Y_{i}$ of the existing assets, as well as the value-added income of the larger assets $K_{i}$ in the process of low-buy and high-selling assets. Only the investment earnings $Y_{i}$ can be obtained as a result of nothing. Therefore, there are far more potential speculators 
than investors. This can easily lead to an oversized capital market that exceeds the economic system's need for asset allocation, especially risk asset allocation, until a full abduction of the factual economy. Just like Kindelberg quoted Walter Bagehot in his book: "Much has been written about panics and manias, much more than with the most outstretched intellect we are able to follow or conceive; but one thing is certain, that at particular times a great deal of stupid people have a great deal of stupid money... At intervals, from causes which are not to the present purpose, the money of these people-the blind capital, as we call it , of the country-is particularly large and craving; it seeks for someone to devour it, and there is a 'plethora'; it finds someone, and there is 'speculation'; it is devoured, and there is 'panic"' [10].

From this perspective, people's behavior of speculation in the capital market is the root cause of the market crisis and its financial crisis. Banning the capital market is the easiest way to put an end to the financial crisis. However, just as it is not possible to drive a car to avoid traffic accidents, the important role of market speculation in deploying risk assets is far greater than its potential crisis. Therefore, even if there is a good virtual economic environment (virtual P/E ratio matches the factual P/E ratio), the characteristics of the capital market's Ponzi scheme determine its potential fluctuations and crises.

\subsection{External Causes}

Classical literature such as Solow (1956), Kaldor (1963), Samuelson (1990) [11] [12] [13], that the ratio of capital to output in production, which is the factual $\mathrm{P} / \mathrm{E}$ ratio $K_{f} / Y$ in this paper, is stable. Because the capital stock is gradually accumulated from the investment over the years, the national economy will have a corresponding increase in fixed assets as the output increases. Using the US statistics "Private fixed assets" and GDP to verify, the average P/E ratio $K_{f} / Y$ for 1970-2017 is 2.226. The average value of the virtual $\mathrm{P} / \mathrm{E}$ ratio $K / Y$ calculated by the Cobb-Douglas function marginal state equation $K / Y=\alpha / r$ is 9.265 from 1970 to 2017, which is 4.162 times the factual P/E ratio $K_{f} / Y$, especially after 2000. The gap between $K / Y$ and $K_{f} / Y$ gradually increases, as shown in Figure 6.

In the 48 years from 1970 to 2017, the trend and fluctuation of the virtual P/E ratio $K / Y$ before 2000 were relatively stable. The average value from 1970 to 2000 was 4.346, which was about 1.98 times of the average value of $K_{f} / Y$ in the same period of 2.186. After 2000, $K / Y$ increased significantly. The gap between the virtual $\mathrm{P} / \mathrm{E}$ ratio $K / Y$ and the factual $\mathrm{P} / \mathrm{E}$ ratio $K_{f} / Y$ can be used to measure the degree of bubble in the market environment.

Although the virtual $\mathrm{P} / \mathrm{E}$ ratio is an important factor in the capital market crisis, when the house property market and its financial crisis occurred in 2008, its virtual $\mathrm{P} / \mathrm{E}$ ratio was $K / Y=13.03$, far less than the 37.05 in 2012. Therefore, the virtual $\mathrm{P} / \mathrm{E}$ ratio is not a sufficient condition for the capital market and its financial crisis. 


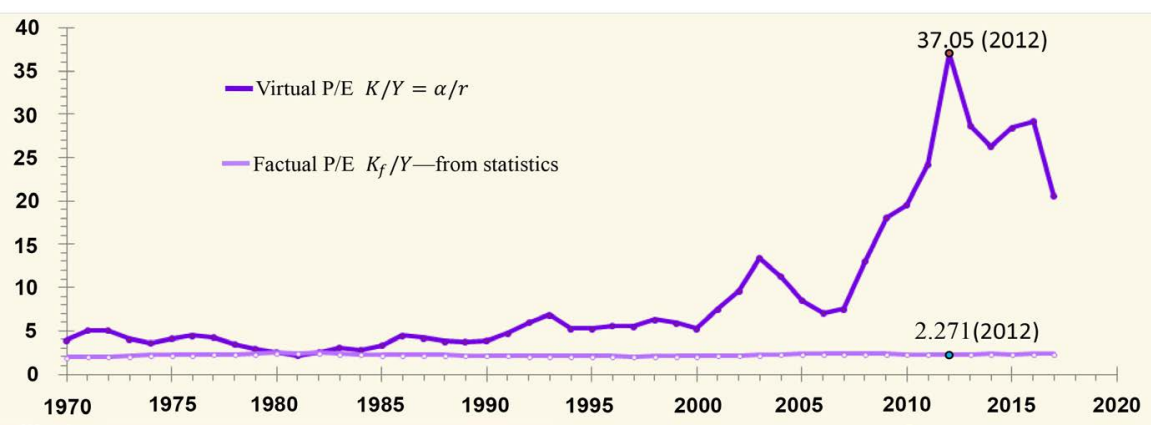

Figure 6. Virtual $\mathrm{P} / \mathrm{E}$ ratio $K / Y$ and Actual $\mathrm{P} / \mathrm{E}$ ratio $K_{f} / Y=\alpha / r$. Resources: 1) $K / Y=\alpha / r$, among them, the interest rate $r$ is the same as Figure 1 , the coefficient of asset allocation $\alpha$ is the same as Figure 3.2) The fixed assets $K_{f}$ and output $Y$ are the same as in Figure 3.

Since the virtual $\mathrm{P} / \mathrm{E}$ ratio is calculated by $K / Y=\alpha / r$, the smaller the interest rate $r$ is, the larger the $K / Y$ is. The factors affecting the change of interest rate $r$ are the production status of the factual economy and the influence of monetary policy. Usually, the impact of the factual economy on $r$ has no greater impact on the monetary authorities' adjustment of the discount rate.

$r$ is the nominal interest rate, which is determined by the real interest rate $r_{r}$ and the inflation rate $\dot{P}$, so the inflation rate $\dot{P}$ also affects the interest rate $r$. In the period of inflation or deflation, even if the Federal Reserve does not use interest rate instruments, the virtual $\mathrm{P} / \mathrm{E}$ ratio $K / Y$ will change. The higher the inflation, the smaller the $K / Y$, so higher inflation is conducive to suppressing the environmental bubble generated by the virtual $\mathrm{P} / \mathrm{E}$ ratio. As shown in Figure 7, the higher inflation rate $\dot{P}$ in 1970-1983 corresponds to a lower virtual P/E ratio $K / Y$, and the higher virtual $\mathrm{P} / \mathrm{E}$ ratio $K / Y$ in 1999-2017 corresponds to a lower inflation rate $\dot{P}$.

In addition, the state of the business cycle is also one of the factors affecting the crisis. During the recession of the business cycle, the growth of output level $Y$ will slow down or even decline. This is not in favor of the decline of the carrier $\mathrm{P} / \mathrm{E}$ ratio $K_{i} / Y_{i}$. The 2008 financial crisis occurred during the recession of the business cycle. It is easy to form a big crisis in the deep adjustment of the capital market and the resonance of the business cycle. On the contrary, in the recovery and prosperity stage of the business cycle, because the output level is still rising, the original higher carrier $\mathrm{P} / \mathrm{E}$ ratio $K_{i} / Y_{i}$ will decline, at least not continue to rise. Since the carrier $\mathrm{P} / \mathrm{E}$ ratio $K_{i} / Y_{i}$ is affected by the virtual $\mathrm{P} / \mathrm{E}$ ratio $K / Y$, $K / Y$ is determined by the interest rate $r$. Therefore, if there is no government intervention, the carrier $\mathrm{P} / \mathrm{E}$ ratio $K_{i} / Y_{i}$ will often exhibit a periodicity that is substantially synchronous with the interest rate $r$.

Compared with the frequency of the stock market's adjustment from the state of endogenous earnings to the state of exogenous earnings, the number of crisis in the housing market is almost negligible. This is because their sources of earnings vary widely. The exogenous earnings of stocks $Y_{i}$ depend on the different and often volatile profitability of IPO companies. The exogenous earnings of 


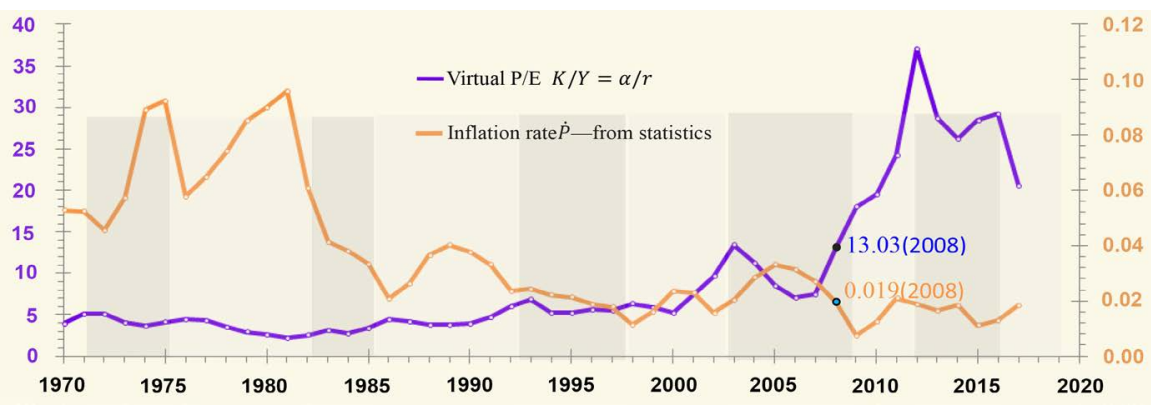

Figure 7. Virtual $\mathrm{P} / \mathrm{E}$ ratio $K / Y$ and Actual $\mathrm{P} / \mathrm{E}$ ratio $K_{f} / Y$. Resources: Virtual $\mathrm{P} / \mathrm{E}$ ratio $K / Y$ is the same as Figure 6, inflation rate $\dot{P}$ is the same as Figure 2.

housing estate is only derived from the rents that are neglected by Adam Smith (determined by the market competitive rental rate). On average, housing rental rates are much more stable than IPO companies' profitability.

Property speculation without monetary policy intervention is far less than the stock market, or property speculation is more dependent on government policy changes in the capital market. The US property and stock market adjustments in 2008 and its financial crisis were due to the continued rise in the virtual P/E ratio $K / Y$ and the broad participation of commercial banks. Without the support of monetary policy and the financial innovation of banks selling subordinated bonds, house prices will not rise sharply until they collapse without a corresponding rent support.

\section{More Data Validation}

To observe three P/E ratios in the 1929 Great Depression, there must be more statistics, the most important of which is the market interest rate $r$. In the previous data, the macro interest rate we used was the average of the yields of Treasury bonds on the market, and the official data on Treasury yields was only after 1969. Fortunately, the "Measuring Worth.com" website provides the first interest rate data in the United States since 1798. There are 6 different types of data: Short-Term Rate: Ordinary Funds, Contemporary Series, Short-Term Rate: Ordinary Funds, Consistent Series Short-Term Rate: Surplus Funds, Contemporary Series, Short-Term Rate: Surplus Funds, Consistent Series, Long-Term Rate: Contemporary Series, Long-Term Rate: Consistent Series. After various trials, only Short-Term Rate The average of Surplus Funds, Contemporary Series and Long-Term Rate: Contemporary Series is the closest to the interest rate we calculated using the annualized rate of return of Treasury bills. As shown in Figure 8, although the average values of Short-Term Rate: Surplus Funds, Contemporary Series and Long-Term Rate: Contemporary Series are generally slightly higher than the interest rate calculated by the annualized rate of return of Treasury bonds (1970-2017, the new average is 0.0645 , and the previous average was 0.0587), but their fluctuations are basically the same, so we use their difference of 0.0058 revised data as the 1920-2017 year interest rate $r$. 


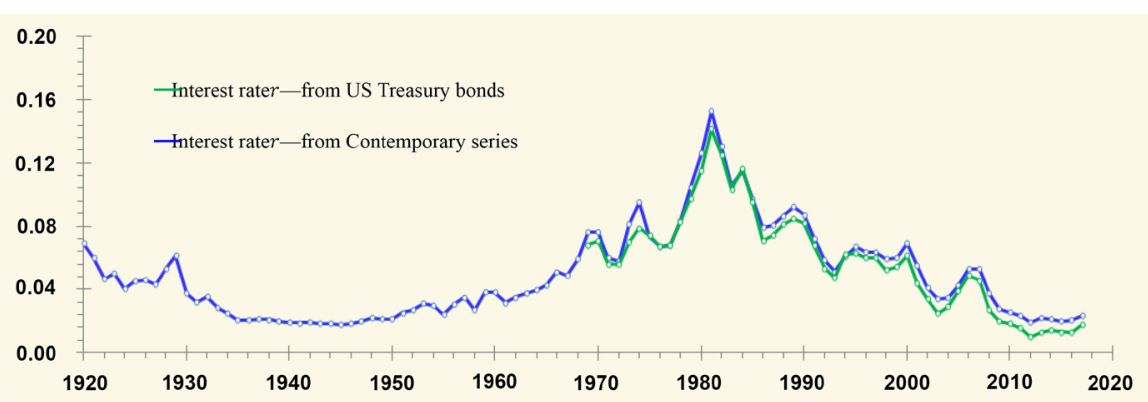

Figure 8. Longer series of interest rates $r$. Resources: 1968-2017 year, the interest rate $r$ calculated by Treasury bonds is the same as Figure 1 . The interest rate $r$ during 1920-2017 is the average of "Short-Term Rate: Surplus Funds, Contemporary Series" and "Long-Term Rate: Contemporary Series". Data are from http://www.MeasuringWorth.com.

Figure 9 shows the change in the virtual $\mathrm{P} / \mathrm{E}$ ratio corresponding to the two interest rates $r$. After 2000, the virtual $\mathrm{P} / \mathrm{E}$ ratio corresponding to the interest rate of Treasury bonds is larger, and the fluctuations are generally consistent with the long series of virtual P/E ratios. The picture shows that both the Great Depression caused by the stock market crash in 1929 and the financial tsunami triggered by the housing bubble in 2008 reflected that the virtual P/E ratio of the external environment is in a bubble state $\left(K / Y>K_{f} / Y\right)$. Before the financial crisis, $K / Y$ was on the rise and the market bubble has accumulated for several years. After the financial crisis, $K / Y$ continues to rise, because The Federal Reserve is trying to stop the recession by cutting interest rates further. It is hard to say that The Federal Reserve should not adopt a monetary policy to cut interest rates after the crisis, because a large number of commercial banks are on the verge of bankruptcy, which will increase the liquidity crisis of the factual economy.

Normally, the market crisis will not occur during the period of rising interest rates, because the virtual $\mathrm{P} / \mathrm{E}$ ratio is determined by the reciprocal of the interest rate $r$, and the higher the interest rate, the smaller the virtual $\mathrm{P} / \mathrm{E}$ ratio. The rise in interest rates will inhibit the rise in the proportion of endogenous returns. Conversely, a fall in interest rates will stimulate an increase in the proportion of endogenous returns until the inflow of funds is exhausted. Therefore, every financial crisis linked to the macro-bubble environment occurs during the period of interest rate decline and also the recession of the business cycle.

According to the relationship between the virtual $\mathrm{P} / \mathrm{E}$ ratio $K / Y$ and the inflation rate $\dot{P}$ in Figure 10, the inflation rate was relatively low before the Great Depression of 1929 and the financial tsunami of 2008. In $K / Y=\alpha / r$, the nominal interest rate $r$ is determined by the real interest rate $r_{r}$ and the inflation rate $\dot{P}$. If the real interest rate $r_{r}$ is constant, the higher the inflation rate $\dot{P}$, the smaller the virtual rate $\mathrm{P} / \mathrm{E}$ ratio $K / Y$ will be. When inflation is more severe, the nominal increase $Y$ in the market is increased more than the increase in asset $K$. This is not good for speculators who are buying long in the capital market. 


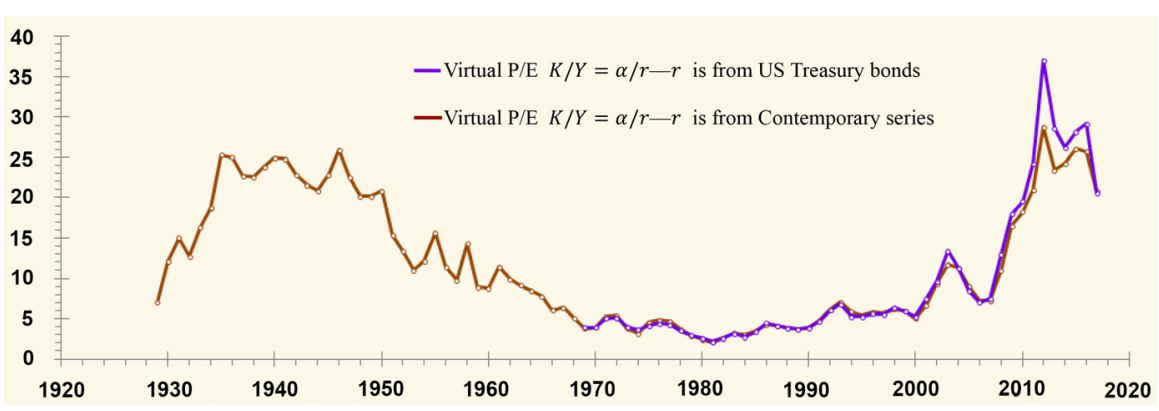

Figure 9. Longer series of Virtual P/E ratio $K / Y$. Resources: 1) $K / Y=\alpha / r, K / Y$ for the period 1969-2017 is calculated from the interest rate $r$ calculated for the same period, the data source is the same as Figure 8. $K / Y$ for the period 1969-2017 is calculated from the average for the period 1920-2017 "Short-Term Rate: Surplus Funds, Contemporary Series" and "Long-Term Rate: Contemporary Series", the data source is the same as Figure 8. 2) Because the coefficient of asset allocation $\dot{P}$ is only 1929-2017 (source is the same as Figure 3), the $K / Y$ data is limited to $1929-2017$.

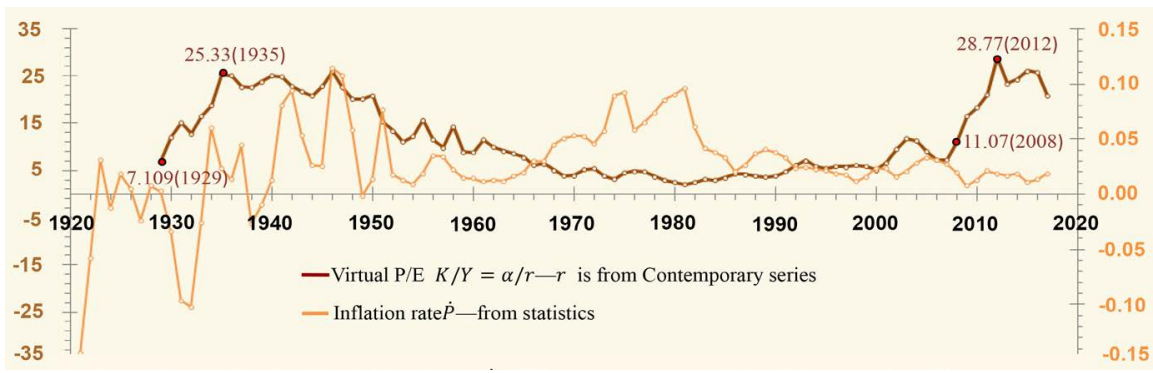

Figure 10. Virtual $\mathrm{P} / \mathrm{E}$ ratio $K / Y$ and inflation rate $\dot{P}$. Resources: Virtual P/E ratio $K / Y$ is same as Figure 9; inflation rate $\dot{P}$ is same as Figure 2.

Figure 10 also shows that virtual $\mathrm{P} / \mathrm{E}$ ratio $K / Y$ is always higher than the factual P/E ratio $K_{f} / Y(K / Y$ in 1929 and 2008 is 7.109 and 11.07 respectively), and $K / Y$ will continue to climb after the crisis until it is much higher than the factual $\mathrm{P} / \mathrm{E}$ ratio $K_{f} / Y(K / Y$ in 1935 and 2012 are 25.33 and 28.77 respectively). This is the post-crisis low interest rate policy syndrome. It has saved many banks and businesses that are on the verge of bankruptcy, while also reducing the efficiency of the economic system.

Table 1 summarizes the internal and external causes of the market crisis and its financial crisis, and lists data for several typical years.

In general, it is much easier to be sure that something will not happen than to be certain that something will happen. The former is the negative judgment while the latter is the affirmative judgment. Negative judgment requires only a few conditions. For example, there is no cloud in the sky, so it will not rain, but even if there is a cloud in the sky, it will not be sure to rain. Similarly, the factors that negate the market crisis will depend on it much less than it must be.

The factors listed in Table 1 are more relevant in showing negative judgments for the financial crisis rather than showing positive judgments. As mentioned earlier, the internal cause crisis can be self-developed and eventually collapsed without external influences like a pyramid scheme. The external-type market 
Table 1. Summary of crisis factors.

\begin{tabular}{lcccccc}
\hline & \multicolumn{2}{c}{ Internal causes } & \multicolumn{4}{c}{ External causes } \\
\cline { 2 - 6 } Year & $\begin{array}{c}\text { Carrier of } \\
\text { speculation. }\end{array}$ & $\begin{array}{c}\text { Carrier P/E } \\
K_{i} / Y_{i}\end{array}$ & $\begin{array}{c}\text { Virtual P/E } \\
K / Y\end{array}$ & $\begin{array}{c}\text { Inflation } \\
\text { rate } \dot{\boldsymbol{P}}\end{array}$ & $\begin{array}{c}\text { Stage of } \\
\text { corresponds to the } \\
\text { business cycle }\end{array}$ & $\begin{array}{c}\text { Bank } \\
\text { involvement }\end{array}$ \\
\hline 1929 & stocks & 20.2 & 7.109 & 0.0025 & recession & highly involved \\
2000 & stocks & 28.2 & 5.070 & 0.0237 & prosperity & NA \\
2008 & $\begin{array}{c}\text { stocks (house } \\
\text { property) }\end{array}$ & $58.9(50.2)$ & 11.07 & 0.0196 & recession & highly involved \\
2012 & stocks & 15.3 & 28.77 & 0.0188 & recession & NA \\
2017 & stocks & 26.0 & 20.81 & 0.0210 & recovery & NA \\
\hline
\end{tabular}

Resources: 1) The stock $\mathrm{P} / \mathrm{E}$ in the carrier $\mathrm{P} / \mathrm{E} \quad K_{i} / Y_{i}$ comes from

https://www.gurufocus.com/economic_indicators/57/pe-ttm-of-sp-500-index, which is the S\&P $500 \mathrm{P} / \mathrm{E}$; real estate $\mathrm{P} / \mathrm{E}$ in 2008 from http://www.wind.com.cn. 2) Data of Virtual $\mathrm{P} / \mathrm{E}$ ratio $K / Y$ and inflation rate $\dot{P}$ is the same as Figure 10.3) The stage of the business cycle is determined by Figure 1.4) We don't have a clear indicator yet to measure whether banks are involved in speculation. Because of the capital market crisis and the banking crisis in 1929 and 2008, banks were considered to be highly involved.

crisis relies on external conditions to generate and grow, and eventually collapses due to insufficient external income. The high degree of bank participation is a necessary condition for further financial crisis on the basis of the capital market crisis, whether it is an internal or external crisis.

The Great Depression of 1929 was an endogenous financial crisis that resonated with the business cycle with the broad participation of banks, because the virtual $\mathrm{P} / \mathrm{E}$ ratio at that time was 7.109 lower than the average value of 11.85 from 1929 to 2017.

Although the Internet bubble burst in 2000 occurred at a higher carrier P/E ratio $K_{i} / Y_{i}=28.2$, the business cycle is still in a prosperous period, so the crisis is limited to the adjustment of the capital market, no banking crisis occurs, and cannot be compared with the financial tsunami in 2008 .

The financial turmoil that swept the world in 2008 has both internal and external causes. The internal cause is speculative in the real estate market driven by financial innovation and the extensive participation of banks. The external cause is the Fed's continuously rising virtual $\mathrm{P} / \mathrm{E}$ ratio.

In 2012, the financial crisis occurred in 2008, and people's speculation was still very cautious. Therefore, the carrier $\mathrm{P} / \mathrm{E}$ ratio $K_{i} / Y_{i}=15.3$ was in the normal range. Although the external factors exceeded 2008, there was no market crisis.

2017 is in the business cycle recovery stage, and the growing output level is conducive to the decline of the carrier $\mathrm{P} / \mathrm{E}$ ratio and the virtual $\mathrm{P} / \mathrm{E}$ ratio (so-called soft landing), so even if the higher carrier price-earnings ratio $K_{i} / Y_{i}$ does not have market adjustment. The carrier $\mathrm{P} / \mathrm{E}$ ratio $K_{i} / Y_{i}$ remains high unless it enters a recession.

Kindelberg said that every financial crisis and bubble bursting method are unique, including the difference between speculative objects, the fraudster's creativity, the impact of accidents, etc. [10]. The tulip bulbs of the winter of 1636 
burst in the spring of 1637 , because speculators realized that the flower growers could immediately multiply the high-priced bulbs. The stock bubble of the British South Sea Company in 1720 is said to be because "English Bubble Act" enacted by the parliament has cracked down on the confidence of speculators.

In 1929 and 2008, there were both capital market crisis and banking crisis, which resulted from the participation of a large number of financial institutions, including commercial banks, in market speculation. Among them, the financial turmoil that swept the world in 2008 also added to the important factor that the Fed began to push up the virtual P/E ratio in 2001. If people only use their own balance of funds to participate in speculation, even if someone goes bankrupt, only wealth is transferred from speculator A to B. But if many financial institutions use the liquidity of production and consumption services for capital market speculation, the market storm will blow from the virtual economy to the factual economy.

Although it is impossible to avoid capital market volatility and crisis, it can still make a difference by restricting commercial banks from participating in market speculation to prevent bank crises. From this perspective, it is better for the financial institutions to operate separately than the mixed operation to benefit the healthy operation of the economic system.

\section{Conclusions}

The long-term return of the capital market is determined by the exogenous income corresponding to the factual $\mathrm{P} / \mathrm{E}$ ratio $K_{f} / Y$. The endogenous earnings come from the continuous increase of speculative funds when the carrier $\mathrm{P} / \mathrm{E}$ ratio $K_{i} / Y_{i}$ increases. The virtual $\mathrm{P} / \mathrm{E}$ ratio $K / Y$ is the opportunity cost of the carrier $\mathrm{P} / \mathrm{E}$ ratio $K_{i} / Y_{i}$, which is affected by the government interest rate policy. The carrier $\mathrm{P} / \mathrm{E}$ ratio $K_{i} / Y_{i}$ driven by speculation is always oscillated by the factual $\mathrm{P} / \mathrm{E}$ ratio $K_{f} / Y$ under the influence of various external factors, especially monetary policy.

In the long run, although the virtual $\mathrm{P} / \mathrm{E}$ ratio $K / Y$ is also determined by the factual P/E ratio $K_{f} / Y$ low-interest monetary policy is often used to combat the recession before the monetary authorities are not aware of the relationship between $K / Y$ and $K_{f} / Y$. This may increase the volatility of the virtual P/E ratio $K / Y$ and the carrier $\mathrm{P} / \mathrm{E}$ ratio $K_{i} / Y_{i}$ confusingly. It is confusing that if we want to reduce the bubble level of $K / Y$ and $K_{i} / Y_{i}$ to raise the macro interest rate $r$, this will be contrary to the countercyclical policy objective. The question is: can asset bubbles really replace the recession? Can the monetary authority only walk the tightrope between them? This is the answer we are looking for in our next paper.

\section{Conflicts of Interest}

The authors declare no conflicts of interest regarding the publication of this paper. 


\section{References}

[1] Zhan, M.A. and Zhan, Z. (2016) A Kind of Neither Keynesian Nor Neoclassical Model (2): The Business Cycle. Open Access Library Journal, 3, e3215. https://doi.org/10.4236/oalib.1103215

[2] Zhan, M.A. and Zhan, Z. (2017) A Kind of Neither Keynesian Nor Neoclassical Model (3): The Inflation Equation. Open Access Library Journal, 4, e3333. https://doi.org/10.4236/oalib.1103333

[3] Zhan, M.A. and Zhan, Z. (2017) A Kind of Neither Keynesian Nor Neoclassical Model (6): The Ending State of Economic Growth. Open Access Library Journal, 4, e3589. https://doi.org/10.4236/oalib.1103589

[4] Zhan, M.A. and Zhan, Z. (2016) A Kind of Neither Keynesian Nor Neoclassical Model (1): The Fundamental Equation. Open Access Library Journal, 3, e3207. https://doi.org/10.4236/oalib.1103207

[5] Zhan, Z. and Zhan, M.A. (2017) A Kind of Neither Keynesian Nor Neoclassical Model (4): The Nature of Philips Curve. Open Access Library Journal, 4, e3388. https://doi.org/10.4236/oalib.1103388

[6] Zhan, Z. and Zhan, M.A. (2017) A Kind of Neither Keynesian Nor Neoclassical Model (5): The Path of Economic Growth. Open Access Library Journal, 4, e3525. https://doi.org/10.4236/oalib.1103525

[7] International Monetary Fund (1998) World Economic Outlook. https://www.imf.org/external/pubs/ft/weo/weo1098/

[8] Smith, A. (1776) An Inquiry into the Nature and Causes of the Wealth of Nations. 5th Edition, Methuen Co. Ltd., London.

[9] Law, J. (1705) Money and Trade Considered, with a Proposal for Supplying the Nation with Money. McMaster University Archive for the History of Economic Thought.

[10] Charles, K.P. (1996) Manias, Panics and Crashes. A History of Financial Crisis. 4th Edition, MacMillan, London.

[11] Solow, R.M. (1956) A Contribution to the Theory of Economic Growth. The Quarterly Journal of Economics, 70, 65-94. https://doi.org/10.2307/1884513

[12] Kaldor, N. (1963) Capital Accumulation and Economic Growth. In: Lutz, F.A. and Hague, D.C., Eds., Proceedings of a Conference Held by the International Economics Association, MacMillan, London, 177-222.

[13] Samuelson, P.A. (1955) Economics. 10th Edition, McGraw-Hill, New York. 